\title{
Creative Destruction: Karl Kraus and the Paradox of Satire
}

(Published in Seminar 49.1, 2013)

The object of satire often bothers the satirist. Of course, satire is nothing but the attempt to ridicule or condemn an object - the venality and decadence of society, the vanity and mediocrity of the literati, and so on. To invoke a recent attempt to determine the constants of satirical writing, the satirizing author seeks to gain the reader's approval for the aggression or negative critical energy he or she directs against an object or experience familiar to both (Schönert 9). But the claim about the bothersome target has an additional meaning: satirists do not want the objects they have singled out for censure to define their art. They may rage against an ugly world, but this, they claim, does not condemn their art to ugliness. Satire should instead be valued for the skill with which someone or something is being criticized or the height from which it is being attacked. In his discussion of satire in Über naive und sentimentalische Dichtung, Friedrich Schiller acknowledges this problem in the process of diminishing its significance:

Stehen wir nur hoch in der Beurteilung, so hat es nichts zu sagen, wenn auch der Gegenstand tief und niedrig, unter uns zurückbleibt. Wenn uns der Geschichtschreiber Tacitus den tiefsten Verfall der Römer des ersten Jahrhunderts schildert, so ist es ein hoher Geist, der auf das Niedrige herabblicke, und unsere 
Stimmung ist wahrhaft poetisch, weil nur die Höhe, worauf er selbst steht und zu der er uns zu erheben wußte, seinen Gegenstand niedrig machte. (742)

According to Schiller, satire is saved from the badness of its object because it is written from a point of great elevation. Society may only seem to be so deeply in decline because of the effect of distance on perception, for it is the high vantage point of the satirist rather than some intrinsic quality that makes the object of satire appear fallen. But Schiller's ingenious rhetoric draws attention to a perennial problem in satire. Satirical writers frequently fear that their work risks being vitiated by the baseness of its material and will turn into yet another medium for the corruption that they want to eliminate.

The writings of the Viennese satirist Karl Kraus (1874-1936) provide numerous illustrations of satire's entanglements, or the troubling contamination of satire by its object. In the pages of his journal, Die Fackel, Kraus occasionally despaired at society's ability to trump his critique by means of its absurd, thought-defying evilness. The intended object of satire, he felt, could overpower the satirical effort. Faced with the horrors of the First World War, for instance, Kraus claimed that he as a satirist was deprived of words. In the article "In dieser großen Zeit," published at the eve of the war, Kraus exclaimed: "Die jetzt nichts zu sagen haben, weil die Tat das Wort hat, sprechen weiter. Wer etwas zu sagen hat, trete vor und schweige!" (2). There can be no playful "victory of intelligence over stupid power" when this power is set in motion to ruin all of civilization (Frye 113). But critically minded readers of Kraus also claimed that his texts inflicted ferocious violence rather than remedied it and thus were as terrible as the society it castigated. According to the author Elias Canetti, once an admirer of Kraus, the audience of the hectoring satirist lived under a sort of dictatorial rule (51). 
Kraus, then, could not escape society's constitution, and some asserted that he embodied some of its worst tendencies. To his supporters, and perhaps to himself, he was unfortunately helpless to remedy the ills of his day and his satire could only reproduce banality and badness. To his critics, his unrelenting rhetoric and command over his supporters turned him into a tyrant in Viennese culture. In the first case, Kraus's satire is deemed helpless to overcome the absolute badness of society by means of critical representation; in the second, the satire perversely reduces critical thought and in this way colludes with the conditions it purports to challenge.

Kraus himself was often frustrated by the constraints and dangers of his preferred genre. Throughout his career, he was haunted by satire's inescapable proximity to the objects of its rebuke, and his work contains a series of attempts to relieve it of its embroilments. At times, he congratulates his victims for being pulled into literary history through his attacks on them; at others, he worries that his satire may never survive his own time and place because of the dead weight of insignificant individuals and events. In both these situations, the relationship of his satire to the objects of its literary aggression, a relationship constitutive of the genre, remains unresolved.

Unavoidably tied to the world that they condemn, Kraus's texts employ a number of escape strategies, and although these moves and arguments do not necessarily follow one another in chronological succession, they can be arranged into a series of steps. This article will reconstruct Kraus's course in the period up to the First World War by identifying three stages in his attempt to distance himself from his satirical target: his renunciation of any loyalty or commitment to the object of his satire; his denial of the assumption that satire has an object corresponding to anything in a shared reality; and, finally, his curious declaration that satire somehow generates its object out of itself, albeit in the form of relentless negativity. The article 
will close with reflections on the contradictions that plague Kraus's always witty and always inventive but still desperate struggle to push an unworthy world out of his satirical art. Even when hate-driven destruction is presented as an entirely independent, indeed creative enterprise and therefore in no way defined by the depravity and banality of all the things it ridicules and condemns, it cannot cut its ties with what it hates. Satire remains uncomfortably associated with the object of critique, and the dignity and meaning of the satirical art is always under threat. Kraus shows us that satire is a troubled, perhaps even anxious, genre.

Kraus repeatedly claims that he is not loyal to his surroundings - the Austrian nation, the city of Vienna, or the profession of literary critics and journalist - and that he does not write out of love. This is partly a reversal of a standard argument made by practitioners of satirical writing. To gain acceptance for their writing among a large audience despite the genre's aggressiveness, satirists often claim to labour for the general health of society. They present themselves as dutiful "public servant[s] fighting the good fight" (Elliott 265). And against accusations of illegitimate destructiveness, they assert a commitment to some now-distant greatness and present their work as a first step toward reform. Among the roles traditionally assumed by satirists in their selfexplications, one finds the teacher, moralist, doctor, and judge, all figures involved in correcting people and the ways of the world (Schönert 38). One could add that vocal nonconformists often present themselves as society's true loyalists, with varying success. A critical opinion, they imply, is less a threat to the cohesion and survival of the group than an addition to its selfunderstanding and an aid in its development; dissent is an epistemic and ethical resource. If the satirist in the tradition of Jonathan Swift is caught urinating on the royal palace, he would probably claim that he was only trying to extinguish a fire. 
As a satirist who seeks to distance himself from society rather than shore up his own acceptability, however, Kraus is not interested in dressing up his rejections as reform-oriented feedback. Instead, he embraces the role of the unnecessarily abrasive figure and portrays his reckonings as serial manifestations of an irrepressible character trait. His savage suggestion to ban reproduction in Vienna, for instance, cannot be understood as a step proposed in the interest of restoring a greater and more authentic Vienna: "Vorschläge, um mich dieser Stadt wieder zu gewinnen: Änderung des Dialekts und Verbot der Fortpflanzung” (“Pro Domo et Mundo” May 1911, 16). By saying that the city will be improved and gain his respect only through its longterm extinction, Kraus subverts the language of reform.

The idea that hate is really, deep down, love, is common in the literature on misanthropes. Reading British literature in the Victorian period, Anthony Lane writes that the period's novelists typically assumed that hatred of people was a "psychological affliction caused largely by unrequited love" (9-10). Familiar with this strategy of reincorporating haters into society, Walter Benjamin claims that Kraus is ill-served by admirers who claim that his hatred has its origins in a more humane affect: "die Herleitung seines Hasses aus Liebe” is, Benjamin writes, "höchst banal und grundfalsch zugleich" (348). The attempts at psychologising hate and turning it into a distorted form of devotion only represent the followers' wish to mediate between their idol and their society. But Benjamin is not alone in arguing that hate cannot be traced back to love. As the phenomenological philosopher Aurel Kolnai points out, the person who hates a particular object is not disturbed by this object's regrettable but ultimately eliminable flaws but by its essential constitution: "Wen wir so recht abgrundtief hassen, den wollen wir keineswegs erziehen und veredeln: Im Gegenteile, es sind nicht seine Mängel, sondern seine Werte, die uns 
stören" (107). Someone guided by love may indeed seek to improve a flawed but cherished object, but the hater's ultimate objective is always to purge the world more completely.

As a self-professed hater, Kraus himself insists that his deep dislike for Vienna and Austrian society was not love transformed by disappointment. Indeed, he derides the notion of hate derived from love in a string of aphorisms: "mein Haß gegen diese Stadt [Vienna] ist nicht verirrte Liebe, sondern ich habe eine völlig neue Art erfunden, sie unerträglich zu finden" ("Pro Domo et Mundo" May 1911, 12). This strategy of repudiation is typically paired with frequent dismissals of the readership. The number of his admirers, Kraus claims, tends to decrease as his writing improves, a negative correlation he takes as evidence of Viennese stupidity. Die Fackel may appear regularly and thus seem like a standard for-profit magazine, but its periodicity only follows Kraus's productivity. Nothing is done for the benefit of the consumer.

Kraus clearly has no interest in placating his audience with assurances of concealed kindness. But his sardonic self-identification as a misanthrope nevertheless does not solve satire's problem of being chained to its object of rebuke. Even hate remains associated with the world it repudiates in a most intimate fashion. Robert Musil, for instance, could point to Kraus's role as a public embodiment of bad conscience: “Kraus ist die Erlöserfigur; dadurch daß Kraus da ist und schimpft, ist alles wieder gut” (Musil 271). In relation to a wider audience, Musil suggested, Kraus's dependable hatred fulfilled a role in the social psyche. He may have railed against Vienna, Austria, or the press, but the readers were soothed by uncompromising performances of affect that nobody else was able to put on. The prophet type did not mobilize the citizens but actually relieved them of any need to speak up, and thus he served the society he castigated by letting its members sink into inactivity. 
More importantly, the satirist's problematic intimacy with the object of critique has to do with the very nature of the affect. Unlike anger, hatred does not erupt in sudden outbursts, but finds a more permanent home in the person whose anger cannot be remedied or is continually refreshed. Hatred is non-episodic, enduring, ossified anger, and colours the way a person views and approaches the world. The psychologist Rolf Haubl speaks of hatred and "Verstetigung"; hatred becomes an integral part of the hating subject's worldview and assumes the stability of a character trait (26). But for anger to stabilize in this way, the emotion requires an object of some solidity that can serve as an inexhaustible source of agitation. Whereas an emotion can flare up at the sight of a flagrant act and then fade away once the situation settles and the emotional resources have been consumed, hatred enters into an abiding relationship with what it hates, even though it wants annihilation. Where there is hatred, there is an "excessive need for the object," or, more precisely, an attachment to the destructive relationship to the object, which must then be preserved along with the relationship (Holbrook 36). Through such a "Daseinsverbundenheit des Fühlenden (Hassenden) mit dem Gegenstande" (Kolnai 111), the object is preserved in hatred, or even comes into being as a clearly bounded object through the process of congealment that accompanies hatred.

Anger stiffens into hatred by attaching itself more permanently to objects not amenable to change. And the objects are protected from flux precisely because the hating gaze serves to bring them into focus and lend them fixity. The belletrist philosopher Peter Sloterdijk even puts forward the idea that hatred is a form of conservation: "Wer sich seinen Zorn merken will, muss ihn in Haßkonserven aufbewahren" (92). Hate's defining characteristics, namely protraction and preservation, make it unsuitable as a means of separation; it is bound to and indeed manufactures stable objects. Hate-driven satire may thus avoid feeding the self-congratulatory attitudes of the 
society it attacks - something that Kraus wants to achieve - but hardly detaches itself from its material. Every time Kraus launches an attack on a journalist, reviewer, author, widespread habit, profession, city, or nation, the object is installed in the text as having attracted his enduring and intense attention. The satirist apparently does not aim for the swift and silent obliteration of its object, but lingers on it and gives it determinate shape in hate. Vienna as a particular place with recognizable, definite properties might even crystallize only under Kraus's hateful gaze. Hate, then, does not sever the problematically close ties between the satirist and his target.

Kraus does have other tactics of disentanglement than explicit declarations of hatred. Quite frequently, he expresses the hope that the objects of his hatred will perish and disappear from public memory although they did find a way into his texts. The audience's acquaintance with the actual people - critics, writers, journalists, businessmen - who do seem to make appearances in his satire can only obscure the true, artistic intent: "Man kennt meine Anlässe persönlich. Darum glaubt man, es sei mit meiner Kunst nicht weit her" ("Nachts" 6). Once the noisy environment of contemporary Vienna has cleared away, however, the satire will become truly readable. Kraus suggests that obsolescence will save his work from the widespread belief that he cares about those whom he seems to write about, or that they themselves are somehow worthy of any detailed treatment: "Meine Leser glauben, daß ich für den Tag schreibe, weil ich aus dem Tag schreibe. So muß ich warten, bis meine Sachen veraltet sind" (“Tagebuch” 15). Unlike authors who long for the day they will finally be understood, Kraus wants certain dimensions of his text to become increasingly inscrutable, so that only the hatred and the virtuosity remain recognizable but not what once seemed to have occasioned them.

Clearly disturbed by the problem Schiller noted in his discussion of satire's unworthy objects, however, Kraus is not about to let time alone purify his writing of distracting dross. To 
fight associations with his contemporary world, he alleges that his satire has only the most tangential and accidental relationship with anything or anyone that he mentions. His writing, he claims, has little to do with its apparent content. People who recognize themselves in his text are deluding themselves about his satire's need for factual material drawn from external reality: "Die sich beleidigt fühlen, unterschätzen mich; sie halten sich für meine Objekte, und da fühle ich mich beleidigt" ("Ein weitverbreitetes Mißverständnis" 2). Claims that any resemblance to real persons, living or dead, is purely coincidental serve to protect Kraus not so much from legal action from the slandered parties as from their banality.

Knowing that these regular disclaimers may not be sufficient, Kraus also seeks to anchor the sovereignty of his satire in the autonomy of art: "Die Würdigkeit der Objekte mag den Wert der Polemik bestimmen; aber Name oder Andeutung eines Kleinen, oder was irgend von ihm in einer Satire steht, ist Kunstelement” ("Ein weitverbreitetes Mißverständnis" 1). While scholars of the avant-garde typically complain about how aestheticization neutralizes literature's desire to intervene in society, Kraus invokes the topos of pure art to insulate his viciousness from the petty indignation of those he targets. He wants no association with the figures his hatred seems to have settled on. The escape into art is perhaps not insincere, but it is strategic. Kraus counts on the readers' assumption that literary texts will entertain less direct relationships with reality than editorials, and enjoy a longer life. In an encyclopedia entry on satire, Helmut Arntzen singles out Kraus as the great champion of satire as a literary achievement rather than a form of political or social intervention. For Kraus, Arntzen writes, satire is a "Kunstleistung," and the artistic work does not emanate from the clear view of moral ideals, as in Schiller, but rather from an intense engagement with language (360). 
Kraus's persistent struggle against misconceptions reveals an author made anxious by the entanglements of his practice. Even hate may not be sufficiently destructive insofar as it still remains bound to the person or thing toward which it is directed. The most theoretically ambitious attempt by Kraus to cleanse his satirical practice from the vice, triviality, and idiocy of Vienna, the press, or the modern world, involves asserting the absolute spontaneity and creativity of his satirical destruction. Seemingly exasperated by the place of the banal inside his own work, Kraus argues that satire is never provoked by anything outside of it, but generates its topic from within:

Den Politikern bin ich ein Ästhet, den Ästheten ein Politiker. [...] Ich meine es anders als beide, wenn ich, fern den Tagen, da ich in äußeren Kämpfen lebte, fern aber auch von den schönen Künsten des Friedens, mir heute den Gegner nach meinem Pfeil zurechtschnitze. Die Realität nicht suchen und nicht fliehen, sondern erschaffen und im Zerstören erst recht erschaffen. (“Apokalypse" 13-14)

As a satirist, Kraus is neither a politician nor an aesthete. The contrast allows Kraus to set up an entire series of oppositions. The politician works to gain power and intervene in society, while the aesthete longs for a sanctuary away from it; politics is the interest in the content of life, whereas aesthetics is the attention to form alone. As other binaries in Kraus's work, the politicsaesthetics polarity is the matrix of countless aphorisms. But what distinguishes satire from these symmetrical positions?

According to Kraus, satire neither desires immersion in some social reality, nor does it seek respite from it, for it does not need or presuppose reality's existence. Instead, satire gives shape to reality in the very process of taking aim at it. Contrary to standard assumptions about satire as a genre that depends on clear and recognizable reference to an already constituted extra- 
textual reality (Schönert 9), Kraus suggests that the textual object he constructs - or constructs by means of destruction - does not correspond to anything that exists in the shared world. Instead, satire projects or creates a well-populated social and political environment in the very process of deriding that environment.

What does such creative destruction, such "im Zerstören [. . .] erschaffen" (“Apokalypse” 14), look like? The pages of Die Fackel offer the reader many examples of how Kraus distinguishes and categorizes the world in concise and damning judgments. To take a very simple example:

Der Geist der Medizin ist leicht zu fassen und ihr Ruf als Kommiswissenschaft steht heute unbedingt fest. Die Juristerei erscheint mir als die Entschädigung von Gaunern, die nicht den Mut haben, es zu sein. Die Philosophie halte ich mir vom Leib, weil ich das Gefühl habe, daß hier tagaus tagein das Schlimmste begibt, und weil ich zu gut informiert werden könnte. ("Philosophen" 40)

In Die Fackel, everyone and everything are quickly captured in a set of neatly bounded classes, all of which represent some special type of inanity, fraud, and vulgarity. Kraus's style of delivery makes determinations, and if he needs only the most minimal encounter with something to pass judgment, it is because what appears in his text is formed by it. Seemingly using building blocks from a world we know, Kraus orders the terrain of his satire through the production of harsh condemnations.

In his aphoristic comments on satire, Theodor W. Adorno recognizes Kraus's capacity for rapid and sharp distinctions: "Kein Witz von Karl Kraus schaudert in der Entscheidung darüber, wer anständig und wer ein Schurke, was Geist und was Dummheit, was Sprache und was Zeitung sei” (240). Yet these characteristics of Kraus's satirical style - its shape-giving, 
boundary-drawing rhetoric - are consistent with the reflections on what we could call hatred's epistemic effects. With his statement on the process of "im Zerstören [. . .] erschaffen"

("Apokalypse” 14), Kraus only draws out the implications of the notion that hate defines and stabilizes its objects. In his exploration of the affect, Kolnai speaks of the "scharfe Herauspräparierung" of objects that is particular to hate (124). Hatred brings the world into focus; it selects and fixes the attention on something or someone that through this process emerges as a contoured and completely knowable thing.

To hate is to be certain about the properties of an object, determine it exhaustively, and claim that it will never be able to overwhelm the observer. For the convinced hater (and the true hater is always convinced), no sceptical reservations about the reliability of human perception can dissolve the sense that the hate toward the object is necessary and legitimate. There are no "conceivable pockets of lurking mitigation" to the subject gripped by hate (Bogel 37). According to James Phillips, in a discussion of the relations between love and trust, on the one hand, and hate and certainty, on the other, the world of hatred is bereft of surprises: "We may leave it to our enemies to know who we are: they are not prepared to give us the benefit of the doubt, to concede us the possibility of pleasantly surprising them" (214).

What is condemned in hatred is seen clearly as something absolutely certain and fixed, and perhaps comes into existence as a defined entity only through this very condemnation. In this sense, the satirist neither seeks nor flees from reality, but identifies, localizes, names, and even constitutes it on the path toward destroying it. It is this creative dynamism (and the promise of increased output) that Kraus says draws him to hate: "Haß muß produktiv machen. Sonst ist es gleich gescheiter, zu lieben" ("Pro Domo et Mundo" Oct. 1911, 8). And some contemporary reviewers whom Kraus cited in Die Fackel were willing to corroborate his statements on the 
productivity of hatred. One favourable review applauds the "schöpferischen Haß dieses Gehirns" ("Notizen" 49). Kraus and his admirers concurred; hate propels rather than inhibits creativity. Kraus speaks about creation in destruction, or "im Zerstören [ . . . erschaffen" (“Apokalypse" 14). The phrase may sound familiar. The Vienna-educated, Austrian economist Joseph Schumpeter, Kraus's contemporary, coined the phrase "creative destruction" to capture the dynamic character of capitalism. According to Schumpeter, entrepreneurs who introduce new goods and open up new markets "revolutionize the economic structure of capitalism from within" (83; emphasis in the original). While this process raises the living standards of all over time, the continual disruptions are bound to have devastating effects on older, established firms and trades. New innovations always condemn previous advances to obsolescence - creation is destructive. In Kraus, however, the relationship between creation and destruction is more direct, more intimate. Instead of a novel product reducing the demand for an old one, an object of derision does not correspond to something external to the text but emerges for the first time in the judgment of damnation cast upon it. Aggression itself is generative.

Seeking to separate himself from the people who claim to be his targets and react with indignation to his art, Kraus declares that he fabricates the enemies he needs for the arrows he already has: "den Gegner nach meinem Pfeil zurechtschnitze[n]” (“Apokalypse” 14). Kraus's choice of image here is informed by literary tradition. The archer who combines watchfulness and deadly force when successfully targeting a victim stands as a model of precise and unsparing judgment. Unsurprisingly, satirists have often been likened to archers. The Jonathan Swift biographer Carl van Doren, for instance, speaks of Swift's "witty marksmanship" (43). The image of archery indeed has a long literary history, featuring among others the vengeful Odysseus, and is also a metaphor used in philosophy. The literary theorist Samuel Weber 
discusses how dominant theories of truth in the Western tradition are persistently accompanied by images of archery:

The correspondence theory of truth, which later will be defined as the adaequation intellectus et rei, presupposes a certain divergence or distance between the thing to be cognized and the thought or representation of it $[. .$.$] The question here is how the gap$ between intellectus and re comes to be bridged, and it is in this context that the figures of archery and of targeting are often invoked. (15-16)

The metaphor of archery thus captures how a judgment should ideally come to correspond to an object external to it; discourse should be responsive to and map reality.

Kraus, however, does not assimilate himself to this venerable imagery of accurate judgment without adding a twist. For him, true satire makes its object fit its arrows, meaning that this object takes shape only in the eyes of the marksman. His writing is, according to himself, precisely not an attempt to come as close as possible to a pre-existing reality and thereby meet the philosophical standard of good judgment; the satirist strives for creative destruction rather than adequacy. Kraus thus insists upon a kind of epistemic independence from a reality supposed to exist "anterior to the satiric attack" (Bogel 2). When creating his texts, he claims not to rely on input. Or it happens that he does admit to gathering material, but then he wittily adds that his sources exist for the sole purpose of providing his satire with inspiration: "Wer braucht denn die Presse außer mir, der sie aber auch nur so lange braucht, als es sie gibt!” (“Nachts” 104). In any case, the poor constitution of the surroundings can in no way do damage to the dignity of his art. If the world itself is a pitiful thing with which he does not want to entertain any relationship, then only his satire raises it up to correspond with the quality of his writing. 
When somebody is satirizing something, we presuppose that the thing about to be demolished first had to be there. Kraus tries to correct this commonsensical assumption about the "temporal priority of the repellent satiric object" (Bogel 3) and in this way resolve the issue of satire's embarrassing reliance on something it rejects as worthless. As a satirist, Kraus does not first discern or even construct an image of something to then be able to tear it down, and he does not rely on an already established terrain, some segment of an authentic historical reality. Rather, he makes a world consisting of sharply defined objects in the process of attacking it. Negation is not a latecomer, for everything that is invented and that appears in the satirical text - critics, journalists, cities, nations, and so on - is already enveloped in derision. The world Kraus writes about arises and exists only in the medium of his mockery.

Kraus seeks to refute the claim that satire inspired by hate is derivative and dependent upon some prior object. He is in fact not obsessed with, and therefore hopelessly attached to, something that possesses a separate, positive existence, but generates everything that he writes about, or destroys, in writing. If we take this to be a rhetorical strategy, we could say that Kraus launches a kind of devious double attack on the world, first berating it for all its flaws and then denying it a real existence. Not only is Vienna corrupt and idiotic, it also does not possess an independent existence outside of Die Fackel's pages. Kraus first publicly humiliates his enemies and then turns his back on them by claiming that he borrowed their names for the sake of an artistic invention and had no particular interest in them. His implicit strategy is to deprive the target of the respect implicit in any real combative engagement between enemies.

But, however ingenious, Kraus's defence of satire as an art of creative destruction proves difficult to sustain. When faced with the international press in the era of world war, Kraus believes he is witnessing a perfect system of misinformation that creates the world it professes to 
represent. In his writings about the intimate relationship between "Katastrophen und Redaktionen" ("In dieser großen Zeit" 11), he points to loops that serve to generate and intensify the disaster of war: "Wie wird die Welt regiert und in den Krieg geführt? Diplomaten belügen Journalisten und glauben es, wenn sie’s lesen" (“Nachts" 106). Or, more generally, the press tends to exaggerate the state of the world that it once helped create, amplifying the crisis every time it passes through the newspaper: "Sie [the press] übertreibt den Zustand der Welt, nachdem sie ihn erschaffen hat" ("In dieser großen Zeit" 14). When set to work, newspapers are able to engender disastrous realities through reverberations. In the words of Kraus: the echo calls forth the cry, the press, the war.

Journalism at war confronts Kraus with an example of conjuration on a world-historical scale, but in the case of the press, the generative dynamic depends on a lack of imagination rather than an excess of it. Out of habit and lack of creative flexibility, editorial offices hungry for sensations deploy an inherited and frequently archaic rhetoric of pathos and patriotism to excite popular belligerence. With limited linguistic resources, they fall back on a pre-established repertoire of phrases about glory and heroism completely inadequate to the technological realities that will entail mass killings. The Kraus biographer Edward Timms writes of his sensitivity to "the disjunction between anachronistic attitudes and technological advances" (150) and later invokes the memoirs of First World War officers to argue that the satirist was right in attacking the "lack of realism in prevailing conceptions of war" systematically fostered by war correspondents (278). Once the war has begun, triggered by the misinformation practices and agitation of the press, the phraseology of heroism and sacrifice becomes bloody reality. Because of its impoverished imagination, however, the press is never truly reached by the horrors that it constantly reports and comments on. It fails first to anticipate and then to comprehend the 
conditions of modern warfare and its unprecedented destructiveness. The press is a "Zauberlehrling" that has summoned a force it cannot control, but, limited by the impoverished language that determines its cognitive scope, it also does not grasp the destruction that it has unleashed ("Nachts" 146).

With devastating results, the press makes rather than mirrors the world. This is suspiciously similar to the idea of creatively destructive satire, and Kraus may have identified the dynamic precisely because it was so close to him. The notion that the press produces a horrendous reality could be particularly plausible to a writer who separates his satire from his supposed targets by insisting on his ability to create a world. Both the press and the satirist shape rather than copy reality, with the difference that the journalists lack what the satirist possesses in abundance, namely imagination. But much like the press, the satirist might be a sorcerer's apprentice, who calls forth a dynamic through creative destruction that he finds himself unable to control. This concluding argument, however, requires a final look at hate.

Hate, psychologists have observed, stems from perceived powerlessness. In studies of workplace relationships, people who see themselves as having little power to escape or improve an anger-inducing situation are more likely to harbour hate than those with the authority to speak freely, issue reprimands, or rearrange their own life context. To cite a piece of contemporary scientific prose, there are "negative correlations between hate intensity and perceived selfpower" (Royzman 17). Yet one does not have to consult modern psychologists to find observations of powerlessness as the generator of hate. Friedrich Nietzsche discusses a similar dynamic under the heading of ressentiment. In his explorations of the genealogy of morals, the priestly caste possesses the same will to rule as the nobles but finds itself too weak to attain political power; its members are sickly, whereas the knights radiate health and vigour. The 
former are, in other words, simultaneously power-hungry and impotent, and as a result they begin to hate their superior rivals. Whereas the lust to rule can fade into resignation in the face of insurmountable obstacles, the Nietzsche scholar Bernard Reginster explains, "[t]he hatred the priest harbors towards his victorious rivals, the knights, 'grows to monstrous and uncanny proportions"' (286). Hatred is, in this Nietzschean account, the result of inhibited vengefulness. To contemporary psychologists as well as nineteenth-century philosophers, hate is likely to arise when subjects are unable to exit situations of powerlessness. But hate as an affect with particular characteristics may also exacerbate the problem of an overpowering world because of its own petrifying effect. Under the hateful gaze, the "utterly knowable" world becomes increasingly motionless and impervious to disruptions, and therefore also shuts out the subject who seeks change (Bogel 37). Hatred puts itself in a position of weakness in relation to its progressively fossilized surroundings. This could make hateful satire self-generating, for it is bound to react with more hate to the world that it has itself turned to stone. Satire may be involved in the creation of a world, but insofar as this creative destruction draws energy and vigour from the affect of hate, it is likely to hold itself in perpetual captivity. Powered by hate, satire will define the world clearly, to the point of rendering it hard and inert. Yet the immobility itself will keep hatred alive, for subjects hate precisely those situations that they are helpless to alter. Hate thus grows ever stronger by eroding the subject's agency. The more the world hardens under the rule of hate, the more it provokes hatred born of helplessness.

Hate involves the fabrication of stable objects, which means that the affect leaves a trail of petrifaction. More and more areas of the world freeze over, making the landscape of the satirist an increasingly predictable place that repels any interventions. Kraus may not admit to this dynamic explicitly, but it can still be discerned in some of his statements. "Ich habe die 
Überzeugung," Kraus says from within his satire, "daß die Ereignisse sich nicht mehr ereignen, sondern die Klischees selbsttätig fortarbeiten" ("Was man im Traum" 25). He means this as a remark on the dreary repetitiousness of the press that absorbs and represents events only through its limited range of phrases and hence does not really encounter or report on anything at all. In the newspaper, there is never anything new, since nothing that occurs could ever manage to penetrate its wall of automatisms. But the statement could also be read against the grain, as an unintentional comment on the peculiar dynamic of satire. The satirical, hateful gaze gives the world definition, but this can serve only to enhance the hatred, for to the person who hates, nothing in the hated object can or will ever change. In a context determined by hate, novelty and hence improvement are impossible, and that is a condition likely to confirm and intensify the hate. The affect reinforces itself by encrusting the world, crowding out the subject's ability to reconcile itself with the surroundings. Perhaps Kraus the satirist is able to refute the charge that satire cannot detach itself from external reality, and yet this feat may not be the victory he hopes for because he would still have to live in the world he made.

For Karl Kraus, the issue of satire's dependence on and independence from the object under attack may have been particularly virulent. On the one hand, he was driven by an outsized desire for self-reliance, shunning even admirers and eventually locking his journal for other writers. He seems to have been willing to sacrifice approval for the sake of autonomy. On the other hand, few satirists have moved as close to their targets of ridicule. Kraus critiques the press by citing it and exposes his enemies by giving them room in his texts. Benjamin speaks of his method of radical mimicry. Yet anxiety over the genre's problematic relation to its material is hardly exclusive to Kraus. Even Schiller seeks to quell the suspicion that the dignity of satire risks being compromised by the vileness at which it constantly directs its attention. Satire 
memorializes that which it seeks to eliminate, pulls into the text what it wants to banish from the world.

This article has sought to follow a thread in Kraus's discourse of self-explication in the period before the First World War. To distance himself from his preferred objects of rebuke and derision, Kraus denies any trace of loyalty or disappointed love, presents himself as a misanthropic hater, and even claims that his creative genius obviates the need for any outside material; resemblances between his satire and his surroundings are merely coincidental. These various deployments of affect and ingenuity are then combined in programmatic statements on "creation through destruction" and the productivity of hatred. Hate does not simply focus on and conserve the object of its attention, but constructs it in the process of negating it. Kraus enlists hatred in his efforts to represent satire not as an object-directed but an object-generating form of writing. Yet it remains unclear whether invocations of hatred allow anyone to escape the dialectic of dependence and independence. Under the gaze of the subject who hates, the world becomes mechanical and predictable and thus ever more deserving of hatred. The selfreinforcing dynamic of hatred threatens to devour the satirist and drain the world of life: in the complete triumph of satire, "the victor reigns [...] over ashes and dead carcasses" (Frye 120).

\section{Works Cited}

Adorno, Theodor. Minima Moralia: Reflexionen aus dem beschädigten Leben. Ed. Rolf Tiedemann. Frankfurt/M.:

Suhrkamp, 2003.

Arntzen, Helmut. “Satire.” Vol. 5 of Ästhetische Grundbegriffe. Ed. Karlheinz Barck. Stuttgart: Metzler, 2003. 345-

64. 
Benjamin, Walter. “Karl Kraus.” Vol. II.1 of Gesammelte Schriften. Ed. Rolf Tiedemann and Hermann

Schweppenhäuser. Frankfurt/M.: Suhrkamp, 1977. 334-67.

Bogel, Fredric. The Difference Satire Makes: Rhetoric and Reading from Jonson to Byron. Ithaca: Cornell UP, 2001.

Canetti, Elias. Das Gewissen der Worte: Essays. Munich: Hanser, 1981.

Elliott, Robert. The Power of Satire: Magic, Ritual, Art. Princeton: Princeton UP, 1960.

Frye, Northrop. “The Nature of Satire.” Satyra: Ein Kompendium moderner Studien zur Satire. Ed. Bernhard Fabian. Hildesheim: Olms, 1975. 108-22.

Haubl, Rolf. “Ärger, Wut, Zorn - Hass.” Was ist Hass? Phänomenologische, philosopische und sozialwissenschaftliche Studien. Ed. Stephan Uhlig. Parodos, 2008. 23-8.

Holbrook, David. The Masks of Hate: The Problem of False Solutions in the Culture of an Acquisitive Society. Oxford: Pergamon, 1972.

Kolnai, Aurel. Ekel, Hochmut, Haß: Zur Phänomenologie feindlicher Gefühle. Frankfurt/M.: Surhkamp, 2007.

Kraus, Karl. “Apokalypse: Offener Brief an das Publikum.” Die Fackel 10.261-62 (13 Oct. 1908): 1-14.

—_. "Ein weitverbreitetes Mißverständnis.” Die Fackel 13.338 (6 Dec. 1911): 1-2.

. “In dieser großen Zeit.” Die Fackel 16.404 (5 Dec. 1914): 1-19.

—. "Nachts." Die Fackel 17.406-12 (5 Oct. 1915): 94-168.

—_. "Notizen.” Die Fackel 13.341-42 (27 Jan. 27 1912): 44-49.

. "Philosophen.” Die Fackel 12.303-04 (31 May 1910): 39-44.

—_. "Pro Domo et Mundo." Die Fackel 13.323 (18 May 1911): 12-23. 
—_. "Pro Domo et Mundo." Die Fackel 13.333 (16 Oct. 1911): 1-13.

. “Tagebuch.” Die Fackel 10.256 (5 Jun. 1908): 15-32.

. "Was man im Traum aufsaugen kann.” Die Fackel 13.331-332 (30 Sep. 1911): 24-25.

Lane, Anthony. Hatred and Civility: The Antisocial Life in Victorian England. New York: Columbia UP, 2004.

Musil, Robert. Tagebücher, Aphorismen, Essays und Reden. Ed. Adolf Frisé. Hamburg. Rowohlt, 1955.

Phillips, James. "Marriage in Jane Eyre: from Contract to Conversation." Bronte Studies 33.3 (2008): 203-17.

Reginster, Bernard. "Nietzsche on Ressentiment and Valuation.” Phenomenological Research 57.2 (1997): 281305. $<$ http://dx.doi.org/10.2307/2953719. $>$

Royzman, Edward, Clark McCauley, and Raul Rozin. "From Plato to Putnam: Four Ways to Think About Hate." The Psychology of Hate. Ed. Robert J. Sternberg. Washington, D.C.: American Psychological Association, 2005. 3-35.

Schiller, Friedrich. Vol. 8 of. Werke und Briefe. Ed. Rolf-Peter Janz. Frankfurt/M.: Deutscher Klassiker, 1992. $706-810$.

Schönert, Jörg. “Theorie der (literarischen) Satire: ein funktionales Modell zur Beschreibung von Textstruktur und kommunikativer Wirkung.” Textpraxis: Digitales Journal für Philologie 2.1 (2011). < $\underline{\text { www.textpraxis.net }>.}$

Schumpeter, Joseph. Capitalism, Socialism, and Democracy. New York: Harper, 1942.

Sloterdijk, Peter. Zorn und Zeit: Politisch-psychologischer Versuch. Frankfurt/M.: Suhrkamp, 2006.

Timms, Edward. Karl Kraus Apocalyptic Satirist: Culture and Catastrophe in Habsburg Vienna. New Haven, CT: Yale UP, 1986. 
van Doren, Carl. "Editor's Introduction.” The Portable Jonathan Swift. Ed. Carl van Doren. London: Chatto and Windus, 1948. 1-46.

Weber, Samuel. Targets of Opportunity: On the Militarization of Thinking. New York: Fordham UP, 2005. 